\title{
A obra de arte enquanto objeto da memória gráfica: um ensaio incompleto
}

\section{A work of art as an object of graphic memory: an incomplete essay}

\author{
Rafa Santana, Eva Rolim Miranda, Solange G. Coutinho
}

memória gráfica, Bajado, obra de arte, representação

$\mathrm{Na}$ ausência de registros visuais dos materiais gráficos comerciais produzidos pelo artista brasileiro Bajado, uma coleção de pinturas de cavalete foi utilizada como corpus principal de uma dissertação de mestrado que objetivou trazer à tona a contribuição de Bajado ao mundo do design gráfico pernambucano e da memória gráfica brasileira. Considerando que a natureza dos impressos efêmeros, tradicionalmente diletos aos pesquisadores em memória gráfica, é diferente da pintura de cavalete; discutimos nesse artigo a pertinência da obra de arte enquanto material de estudo desse campo de pesquisa.

graphic memory, Bajado, work of art, representation

In the absence of visual records of the commercial graphic materials produced by the Brazilian artist Bajado, a collection of easel paintings was used as the main corpus of a master's dissertation that aimed to reveal Bajado's contribution to the world of graphic design in Pernambuco and Brazilian graphic memory. Considering that the nature of ephemeral forms, traditionally the preference of researchers in graphic memory, is different from easel painting; in this article we discuss the applicability of a work of art as a study material for this field of research.

\section{Notas introdutórias}

Este trabalho apresenta uma discussão a partir da pesquisa de mestrado, finalizada em outubro de $2020^{1}$, ou, mais especificamente a um dos problemas que não foi solucionado naquele momento. Aliás, é um problema que, para nós, continua em aberto. Trata-se das questões que envolvem a natureza do objeto da memória gráfica, mas para isso precisamos fazer um pequeno relato sobre como e por que chegamos a ele. Inicialmente, nosso trabalho buscava fazer emergir a contribuição de Bajado ao conjunto da memória gráfica brasileira e pernambucana; em verdade o desejo de trabalhar com Bajado era, naquele momento, a nossa prioridade ${ }^{2}$.

\footnotetext{
${ }^{1}$ Ver Santana (2020): Bajado a poética visual no discurso gráfico: diálogo entre a semiótica estruturalista e o design da informação, desenvolvida no PPG-Design, UFPE, linha de Design da Informação com ênfase na Memória Gráfica Brasileira.

${ }^{2}$ Porque em comparação com o tratamento dado a outros artistas canônicos de Pernambuco (como Brennand), Bajado, na condição de artista popular e naïf, é pouco estudado e sua produção ainda é conhecida por uma minoria seleta de designers brasileiros.
} Curitiba | Brazil | 2021 
Bajado (1912-1996) foi um artista gráfico (letrista, cartazista, muralista, linotipista, quadrinista, etc.) que ficou mais conhecido por sua produção enquanto artista plástico. Desse modo, logo no início da pesquisa, nos deparamos com os seguintes problemas e questões: (1) muito se falava em jornais e conversas informais sobre uma vasta produção de artefatos criados por Bajado pertencentes ao universo do design (murais comerciais, capa de disco, embalagem de pão, cartazes de filmes, charge de jornal), mas em nenhum acervo público constavam registros visuais desses artefatos (Santana \& Miranda, 2019); (2) restando como opção acessível a sua produção de cavalete (pinturas em tela) disponível em coleções públicas ou privadas, e levando em consideração que obras de arte não são objetos efêmeros; no caso da produção de Bajado, seria legítimo estudá-la enquanto objeto de memória gráfica? Salientamos também a importância da preservação e registro dos artefatos artísticos em questão pelo fato da maioria deles ter como suporte a folha de madeira.

Os próprios rumos da pesquisa, assim como outros temas da teoria da comunicação visual, nos levaram a elaborar um estudo do discurso poético pelo método da semiótica plástica; e terminamos a oferecer um diálogo inicial entre alguns teóricos utilizados pelos pesquisadores do Design da Informação (Bertin, 2010 [1967]; Ashwin, 1979; Twyman,1985,1982,1979) com alguns teóricos da semiótica estruturalista (Greimas, 2004 [1984],1966; Floch, 2004,1985). Assim, nos dedicamos as autorrepresentações de Bajado ${ }^{3}$ e elaboramos uma axiologia do seu regime de presença, deduzindo ser aí onde residia a semântica fundamental geradora do sentido no universo semântico de toda a obra do artista. Portanto, o problema da natureza efêmera do objeto da memória gráfica não foi devidamente mitigado, voltando ao término da pesquisa como um fator a ser explorado.

Esta é a problemática que trazemos ao debate, para tal apresentamos os seguintes tópicos que pretendem elucidar a discussão: (2) notas teórico-metodológicas; (3) a superfície bricolada e sua externalidade: da pintura à memória gráfica; e, (4) notas finais.

\section{Notas teórico-metodológicas}

Priscila Farias e Marcos Braga no panorâmico texto: "O que é memória gráfica" (2018, p. 10) definem memória gráfica no contexto de países de língua portuguesa e na América latina como "uma linha de estudos que busca compreender a importância e o valor de artefatos visuais, em particular impressos efêmeros, na criação de sentido de identidade local". De fato, a maioria das pesquisas em memória gráfica versam sobre efêmeros, ou, no mínimo, objetos tradicionalmente do mundo do Design: rótulos comerciais, capas (de disco, livro, revistas, etc.), elementos intrínsecos aos periódicos (tipografia, ilustrações, charges, etc.), cartões postais, uma verdadeira infinidade de objetos nessa categoria.

Durante a dissertação, no processo de fundamentação teórica em paralelo com a prática de análise das imagens, observamos alguns pontos salutares para o entendimento das fronteiras

\footnotetext{
${ }^{3}$ Uma das principais características da obra desse artista é sua participação icônica nas cenas por ele pintadas.
} 
entre o pensamento dos semioticistas, designers e teóricos da arte utilizados na pesquisa ${ }^{4}$. Observamos que no caso dos semioticistas, a abordagem não é contextualista e seguem uma lógica internalista ao objeto estudado (nada que estiver fora do texto visual interessa ao pesquisador) - o texto é circunscrito numa concepção relacional e estrutural, nele há todas as informações necessárias para sua significação.

Os designers, por sua vez, são inevitavelmente contextualistas, pois sua lógica quase sempre considera um objeto que será interpretado por um usuário - por isso, é de considerável importância o contexto em que esse objeto será utilizado e a cosmovisão do usuário pensamento que naturalmente é externalista ao objeto estudado.

No caso dos dois teóricos da arte que serão aqui explorados, um deles é adepto de história cultural da arte baseando-se numa psicologia social dos estilos (Gombrich); e outro que trata a obra de arte enquanto objeto complexo que finaliza uma intenção inicial do artista, mas que possui certa independência, ao ponto de que a interpretação final - a resposta do observador será sempre subjetiva e praticamente intangivel em generalidade (Wollheim).

A partir desse estado de coisas, na última seção da dissertação, fizemos um pequeno experimento sobre as possíveis intenções e referências (da formação do olhar do artista) e as percepções e feitos técnicos que sua obra nos causam. Nosso objetivo foi identificar as informações externas à obra do artista, ou seja, referências do mundo natural, da cultura visual ao qual ele esteve inserido e que possivelmente influenciou na formação do seu repertório figurativo. Para isso utilizamos a técnica do cruzamento de dados coletados em acervos e hemerotecas públicas, assim como outras fontes de natureza bibliográfica e biográfica (Cuentro, 1985; Prado, 1997; Pinheiro, 2016). Este artigo, portanto, é o relato demonstrativo entre o que foi formulado na teoria e o que foi possível perceber nas telas durante o experimento realizado. ${ }^{5}$

No texto original utilizamos o termo superfícies bricoladas em aderência a epistemologia de toda dissertação, ou seja, fazendo referência ao termo bricoleur (originalmente de Lévi-Strauss e apropriada do Jean-Marie Floch (2004) no estudo sobre Jörg Immendorff) que nada mais é do que a atividade criativa desempenhada pelo artista ao "armazenar" psicologicamente uma

\footnotetext{
${ }^{4}$ É importante frisarmos que nos referimos aos teóricos utilizados na pesquisa e não a "todos" os teóricos das referidas áreas. Inclusive, utilizando como exemplo, na própria semiótica coexistem várias abordagens.

${ }^{5} \mathrm{O}$ corpus original trabalhado na dissertação é formado por quarenta pinturas (de onde foi selecionada a amostra das oito obras acima mencionadas para a análise estrutural), do acervo da Casa Bajado de Arte, a saber: Vendedores (1965), Maracatu (1972), São Jorge dos jangadeiros (1972), Brincantes (1972), O Boi da Vila (1972), Hoje tem Espetáculo (1972), Passistas (1972), Santa Cruz no Carnaval (1972), O Frevo é Bom (1972), “...e a jangada voltou só...!" (1972), O Farol de Olinda (1972), Gafieira Gato Blum (1972), O Velho Canela de Aço (1972), Samba (1972), Samba de Roda (1972), Viva São Jorge (1972), O Touro da Vila (1973), O Boi da Vila (1973), Pitombeira dos 4 Cantos I (1973), Pitombeira dos 4 Cantos II (1973), Carnaval na Praia (1973), Missa dos Cangaceiros (1975), O Boi da Vila (1975), Urso (1975), Olinda no Frevo e O Homem da Meia-Noite (1975), Olinda Terra da Felicidade (1975), Caboclos de Olinda (1975), Festa de São João (1976), Boi Bumbá (1976), Circo Nerino (1976), Urso do Rosário de Olinda (1976), O Nosso Maracatu (1976), O Nosso Maracatu (1976), São Sebastião (1977), Bloco do Cajú (1977), Serenata (1977), Circo - O Amigo da Onça (1980), Carnaval em Olinda (A Mulher do Dia, Pitombeira, Elefante e Vassourinhas) (1980), O Homem da Meia-Noite e Bajado (1980) e O frevo é nosso - O Amigo da Onça (1987). Neste artigo alguns destes quadros, ou pormenores deles, são utilizados de maneira demonstrativa das categorias temáticas levantadas ao longo do texto. Deste modo, admite-se que não houve um procedimento sistemático ou critérios previamente elaborados para a seleção dos quadros ou dos pormenores aqui utilizados .
} 
vasta quantidade de imagens conhecidas ao longo de sua vida e "reordená-las" de um jeito novo particular ou simplesmente bricolado. No caso de Bajado, por exemplo, é comum vermos cowboys hollywoodianos desempenhando o papel de batuqueiros em cenas de cortejo de maracatus.

Essa característica não só é destacadamente marcante na obra de Bajado assim como se tornou representativa no imaginário popular de modo que as pessoas da Olinda alta (parte do sítio histórico) guardam memórias remotas quando confrontadas com as pinturas de Bajado.

Quanto a isso,

A memória gráfica lança mão de postulados associados a estudos sobre memória coletiva ao partir do pressuposto de que seus objetos de pesquisa são parte integrante da cultura de um povo. A cultura é resultado do convívio social. Portanto seus elementos fundamentais são necessariamente partilhados e coletivos [...] nesses estudos, a memória individual deve ser considerada desde que reflita aspectos culturais. (Farias \& Braga, 2018, p.17).

Figura 1: Bajado compondo painel no muro da igreja do Amparo. (Fonte: Acervo Galileu Coelho, 2014 ${ }^{6}$ )

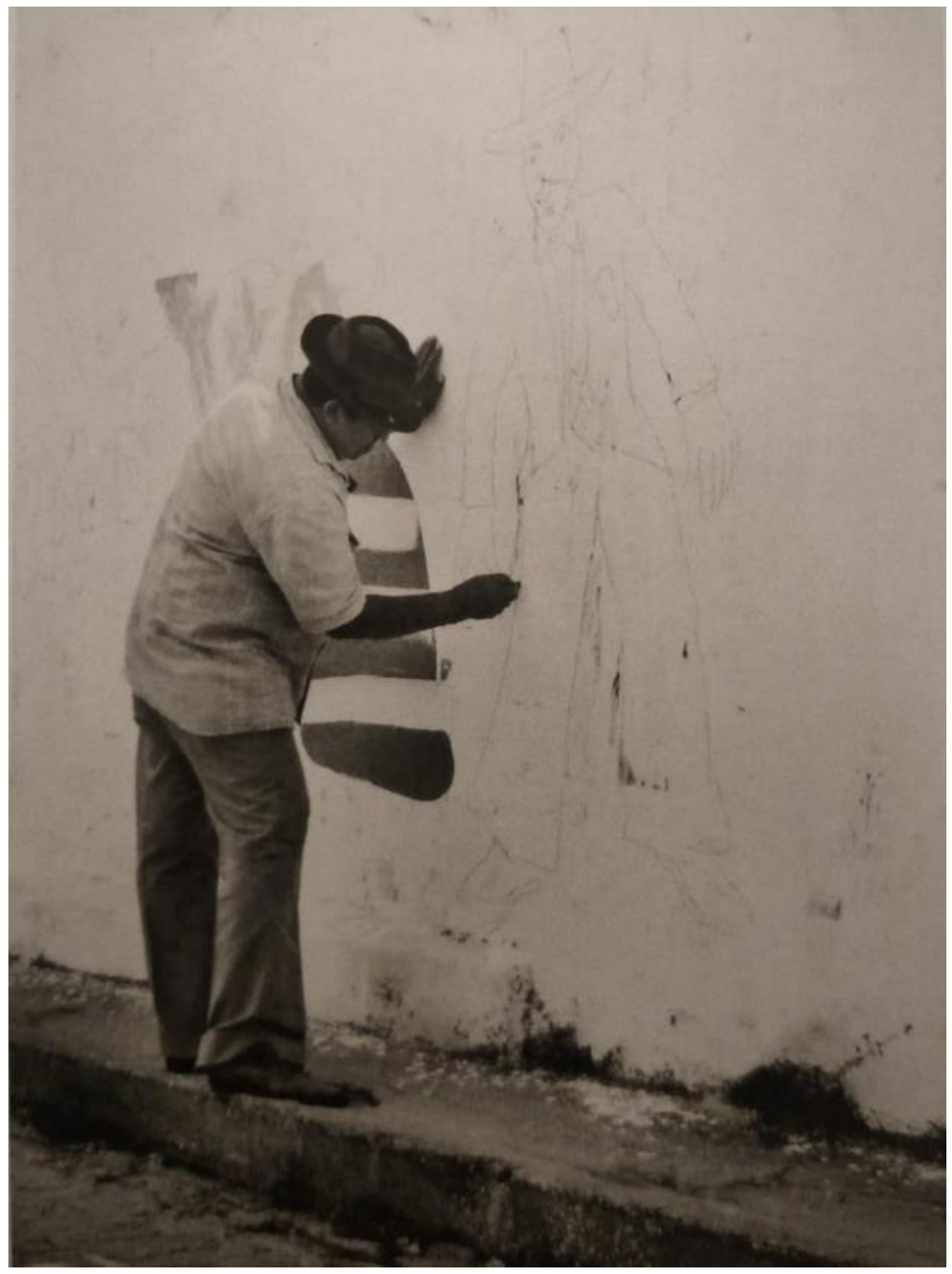

${ }^{6}$ Olinda: memórias fotográficas. Recife: O Norte Oficina de Criação, 2014 (fotolivro). 
Bajado era muito requisitado para elaborar trabalhos gráficos que faziam parte do cotidiano dos moradores de Olinda. Em meados das décadas de 1950 a 1980 era comum para um morador do sítio histórico encontrar uma obra de Bajado na padaria, no mercadinho, na farmácia, no açougue, na peixaria, nos muros das casas em épocas de eleição política, etc. (figuras 1 e 2). Sobre esse ponto, Farias e Braga (2018, p.18) pontuam que "há um resgate de fundo histórico, um processo de ressignificação dos artefatos, com variados níveis, e a constituição de uma memória gráfica, material e cultural, que é também a (re)constituição de uma memória coletiva em seus aspectos culturais".

Observamos que Bajado não alterava o estilo das suas figuras de modo que o boi que ele pintava para o açougue era "irmão" do boi das suas várias séries de cortejos de bois-bumbás. Igualmente, que as mesmas figuras femininas e masculinas que serviam para identificar os toilettes nos bares e restaurantes também protagonizavam os desfiles de maracatus, grupos de passistas e demais figuras humanas que compunham as narrativas das suas pinturas de cavalete. Analogamente também era comum ver personalidades da cultura popular sendo reproduzidas por seus pincéis, de modo que o personagem que as pessoas viam na televisão e no cinema, também poderia ser visto nas pinturas.

Figura 2: Bajado criou a arte para as sacolas da padaria Divina do Amparo. (Fonte: Cinemateca pernambucana, $2020^{7}$ )
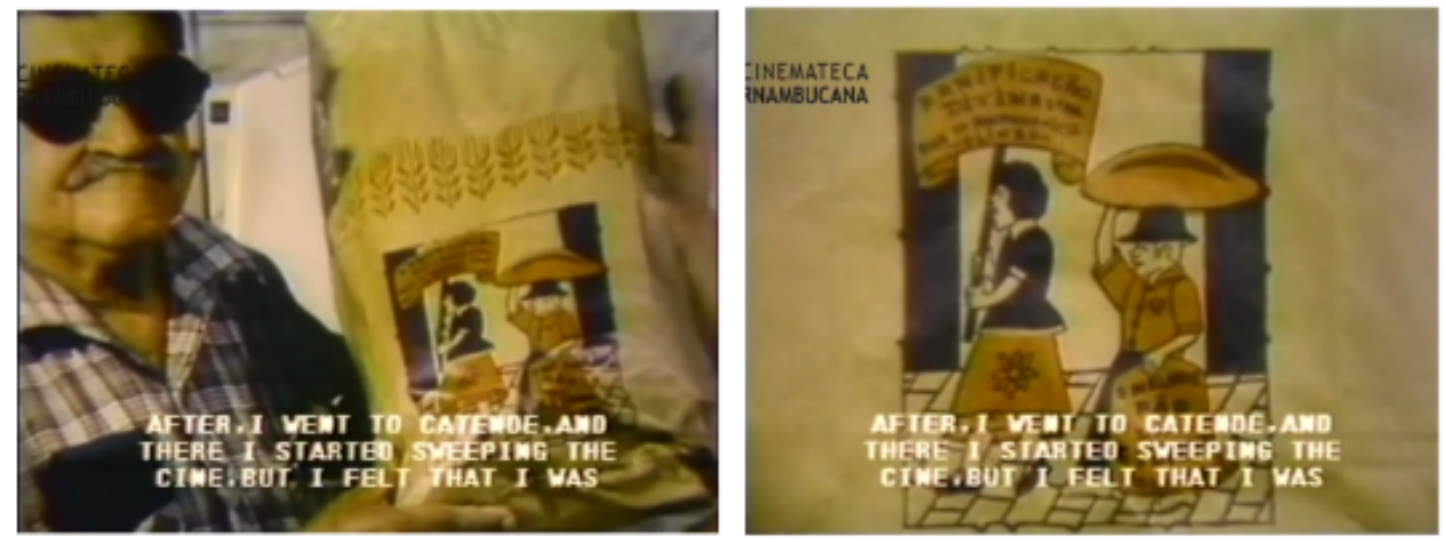

Tudo isso nos leva a considerar que, mesmo sendo obras de arte, é possível que estudemos os trabalhos de Bajado enquanto objetos de memória gráfica, ainda que não sejam duráveis ou não tenham sido projetados para serem efêmeros. Digamos que é o caminho inverso as pesquisas sobre efêmeros, em que objetos projetados com o intuito de serem descartados, pelo tempo, pela limitação técnica e/ou pelo contexto, se tornaram objetos históricos e de interesse da memória gráfica.

Se "artefatos gráficos vernaculares ou populares são assunto de interesse recorrente para os estudos sobre memória gráfica” (Farias \& Braga, 2018, p.13), por equivalência e similaridade estilística, podemos e devemos olhar para os quadros de Bajado como artefatos

\footnotetext{
${ }^{7}$ Foto capturada do filme Bajado um artista de Olinda de Kátia Mesel (1981). Disponível em: <http://cinematecapernambucana.com.br/filme/?id=2501>
} 
artísticos com marcas expressivas dos trabalhos efêmeros do artista; e veremos que em nada contradizem suas funções enquanto artefatos gráficos que "desempenham um papel importante na vida cotidiana, por meio de experiências comunicacionais e em nossas interações com o entorno urbano" (Ibid, p.11) e que ainda são importantes "para a constituição de uma cultura visual que contribui com a elaboração de identidades coletivas" (idem).

\section{A superfície bricolada e sua externalidade: da pintura à memória gráfica}

De acordo com Wollheim, a obra só surtirá o efeito desejado ${ }^{8}$ se o observador possuir as capacidades de; "(a) ver em; (b) percepção expressiva; (c) experimentar o deleite visual"; e se o artista souber manipular os poderes de "(a) representar objetos externos; (b) expressar fenômenos mentais internos; (c) induzir uma forma especial de deleite" (Wollheim, 2002, p.45). Considerando que o nosso objeto são as representações, focaremos agora em nossa capacidade de "ver em" e no poder de Bajado de representar objetos externos.

Wollheim (2002, p.21) diferencia representação, figuração e tematização afirmando que "a tematização da imagem engendra a representação - [...] representação, não a figuração, que é uma forma específica de representação, na qual identificamos a coisa que vemos na frente de outra"'. Exemplificando: ao vermos um quadro em que há um homem na janela, temos uma representação; ao identificarmos esse homem (Bajado, Da Vinci ou Van Gogh, etc.) passamos ao nível da figuração; se esse homem foi "criado" por ele mesmo, teremos o autorretrato como tematização.

\footnotetext{
${ }^{8} \mathrm{O}$ autor explica que essa construção é hipotética no sentido de que tenta responder "o que seria necessário para que a comunicação entre o artista e o observador fosse totalmente eficaz". Porque Wollheim acredita no pressuposto de que existe uma diferença clara entre o que o artista faz e o que o observador vê. O estudo dele discorre sobre as possibilidades de "solucionar" esse problema (para quem acredita que isso seja um problema).

${ }^{9}$ Retomamos essa questão nas notas finais.
} 
Figura 3: Bajado e sua janela e recortes da pesquisa. (Fonte: Cuentro, 1985 e Casa Bajado de Arte)

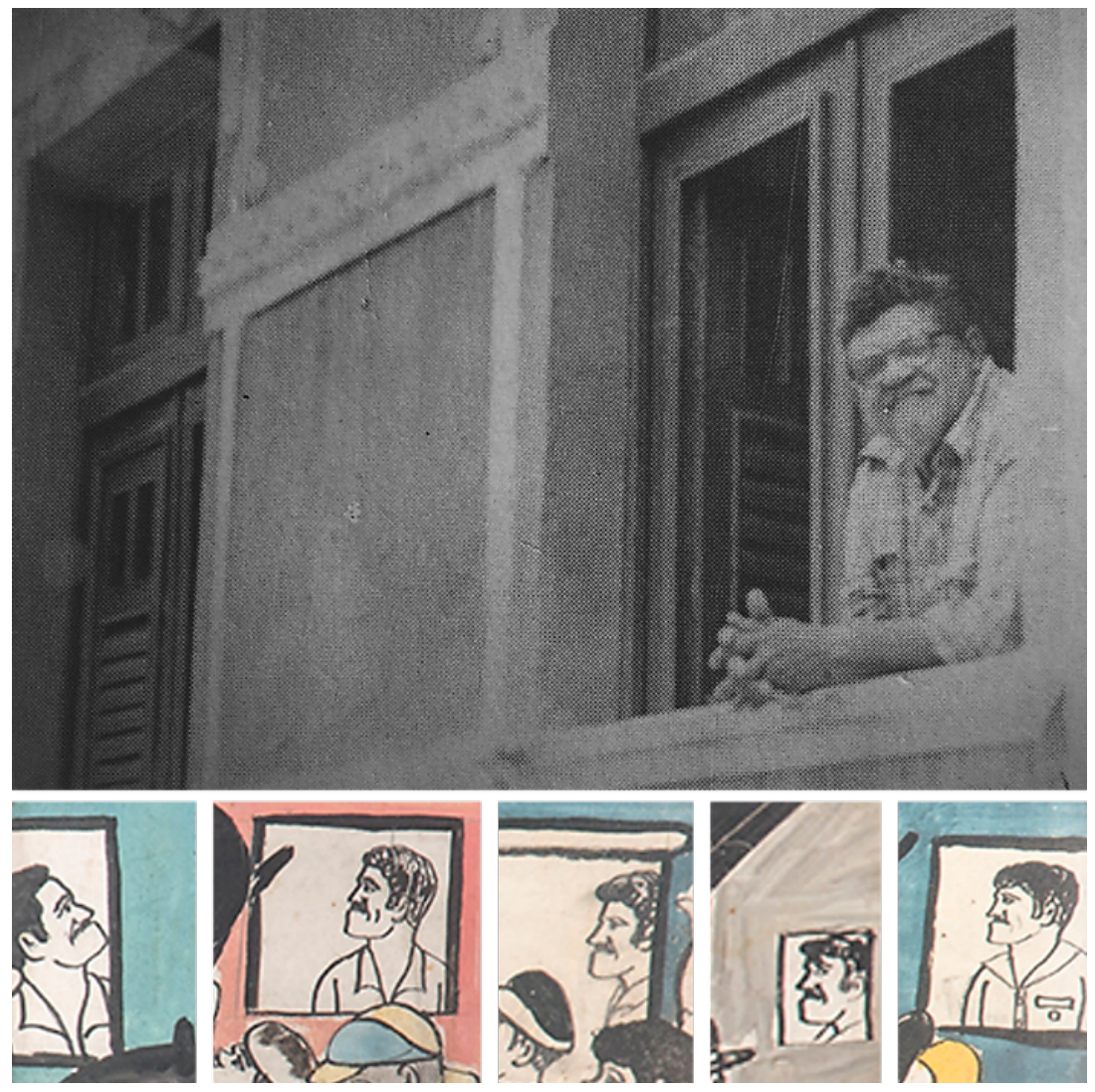

Começando pelas representações do próprio artista (figura 3), observamos que a altura da sua janela é quase sempre superior ao nível da rua e quase sempre está, topologicamente, acima dos demais personagens. Evidenciando uma aderência ao seu referencial do "mundo natural" ${ }^{10}$, pois a casa onde Bajado morou na Rua do Amparo estabelece a mesma relação de desnivelamento com o nível da rua. A casa também está localizada na fileira poente da rua e Bajado, aparentemente, tinha uma predileção em se retratar olhando para a direção esquerda; o sentido esquerdo da rua do Amparo é aquele que leva até os Quatro Cantos.

Diferentemente do restante da rua do Amparo os Quatro Cantos é marcado pelas vielas mais estreitas e com níveis mais acidentados. Assim podemos entender a perspectiva escalonada e sobreposta tão marcantes dos cenários de Bajado (figura 4). Observemos que até mesmo as paredes em ambientes internos repetem as características urbanísticas das cidades barrocas (famosas pelo aspecto intencionalmente labiríntico) que no caso de Olinda se adiciona a característica desnivelada e escalonada típicas de uma acrópole.

\footnotetext{
10 Sobre esse ponto, é importante frisar que os greimasianos não acreditam na relação comparativa entre representação pictórica com o referencial do mundo natural. Para esses autores, o que o artista cria faz parte exclusivamente do microuniverso semântico por ele criado.
} 
Figura 4: A perspectiva e as cores de Olinda. (Fonte: Santana e Casa Bajado de Arte)
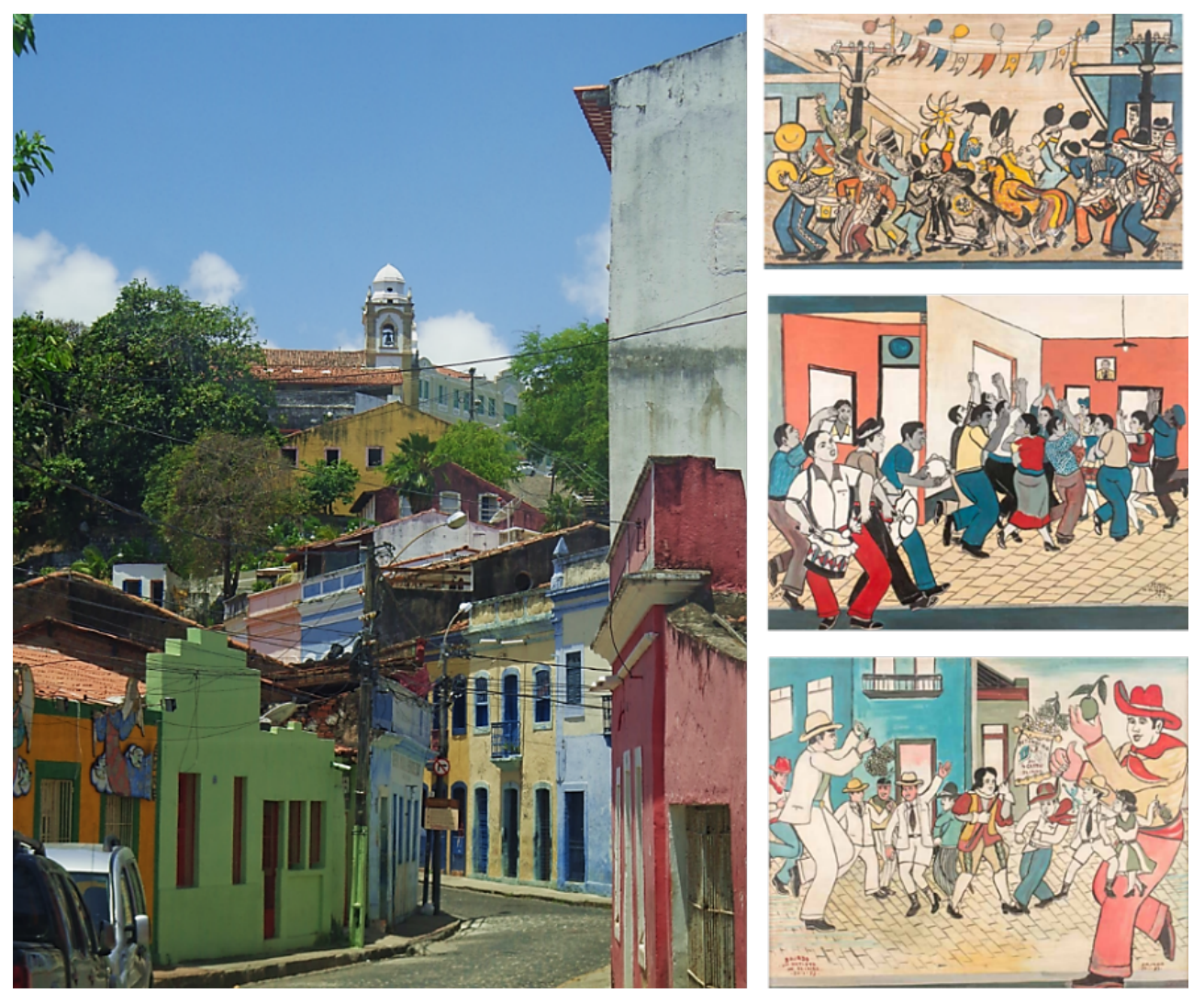

As cores também acompanham a cartela da cidade. Em Olinda, frisos, portas e paredes não obedecem a um padrão de matiz; nem de combinação de matizes para portas e frisos, por outro lado predomina no casario o tom pastel. Em Bajado visualizamos contrastes que vão desde o cromatismo ao acromatismo, como também os contrastes entre os tons pastel e os tons mais saturados, mas de um modo geral a paleta de Bajado é muito próxima à paleta de Olinda (figura 5). Ou, afirmado mais apropriadamente, a percepção cromática de Bajado que foi "transcrita" para a tela é, de certo modo, próxima ao referente do mundo natural. 
Figura 5: Cores de Bajado. ${ }^{11}$ (Fonte: Elaborada por Santana com a ferramenta do conta gotas)

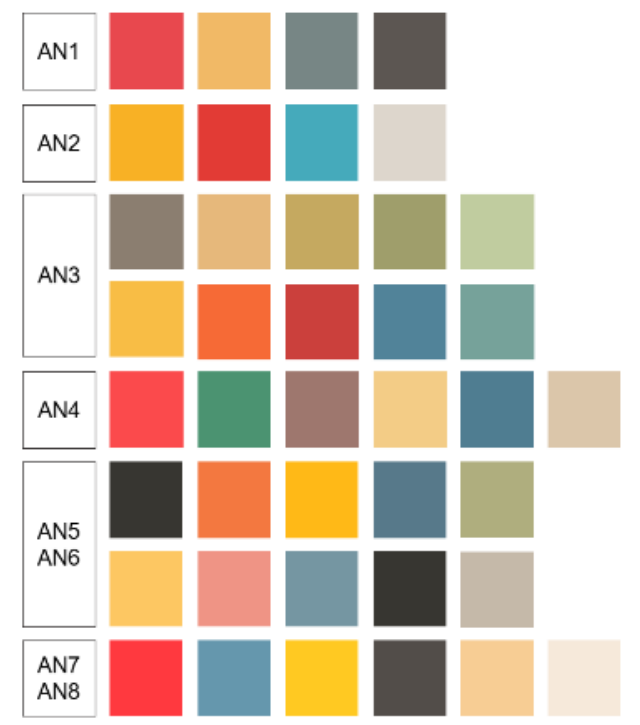

Para Gombrich (que tinha entre outros interesses a predileção pelo problema da percepção visual elencada a uma psicologia social do estilo), os artistas não pintam uma paisagem tendo o mundo natural como referência, segundo ele, "qualquer artista que deseje fazer o registro fiel de uma forma individual não começa com a sua impressão visual, mas com a sua ideia ou conceito" (Gombrich, 2012, p. 96). Nesse sentido, há uma discordância parcial entre o pensamento de Gombrich e Wollheim, pois os enquadramentos, a perspectiva e as cores, seriam evidências da intenção de Bajado que, na visão de Wollheim, ao

marcar a tela de modo a assegurar que o espectador não se limite a reconhecer, mas consiga ver, ver no quadro, o que ele quer representar [...] implica que o artista deve apoiar-se, em qualquer circunstância, em suas crenças perceptivas. Essas certezas perceptivas devem contribuir diretamente para a feitura da representação, e isso significa que elas serão incluídas na intenção do artista (Wollheim, 2002, p.52).

Podemos considerar as discordâncias como parciais porque para Gombrich o artista pinta a partir da imagem ideal daquilo a ser representado; e para Wollheim o artista pinta com base na percepção que ele tem daquilo que quer representar. As representações de corpos em movimento são recorrentes na obra de Bajado, seja coreografando o ritual do maracatu, girando numa ciranda, dançando frevo; os personagens do artista parecem quase sempre capturados como em uma fotografia. Sabemos que esse efeito é produzido por Bajado pelo deslocamento dos pontos de equilíbrio corporal das figuras. Assim como podemos observar na pose da torcedora do Santa Cruz (figura 6).

\footnotetext{
${ }^{11}$ Referente às oito telas analisadas na dissertação $\left(A=\right.$ Análise $+N^{\circ}=$ Quadro); portanto, Viva São Jorge (AN1); São Jorge dos jangadeiros (AN2); A missa dos cangaceiros (AN3); Homem da Meia Noite e Bajado (AN4); Boi da vila (AN5); Boi bumbá (AN6); Nosso maracatu I (AN7) e Nosso maracatu II (AN8).
} 
Figura 6: Ponto de equilíbrio dos passos de frevo. (Fonte: Museu da Cidade do Recife) ${ }^{12}$
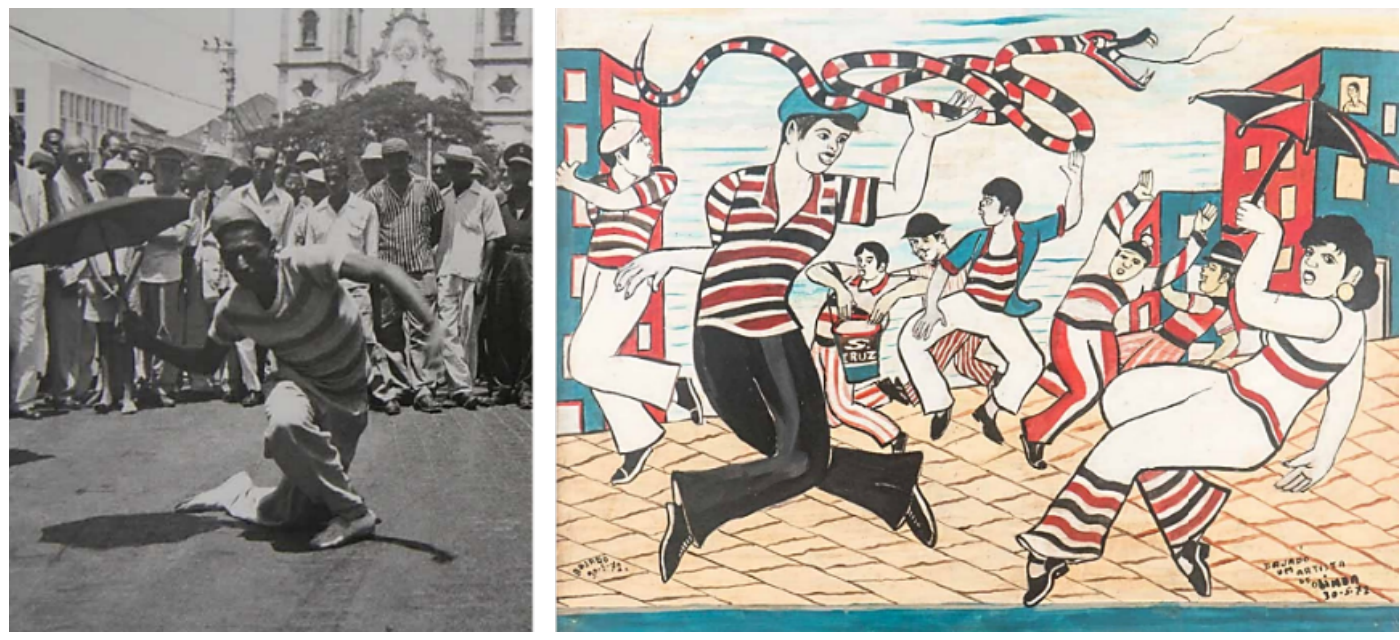

O passo de frevo mais reproduzido por Bajado é aquele popularmente conhecido como "tesoura" (figura 6). Nas pinturas, ele é executado por pierrôs, colombinas, Las Ursas, torcedores do Santa Cruz. A cinética nos quadros de Bajado evidenciam que "o que pode ser representado é coextensivo ao que pode ser visto" (Wollheim, 2002, p.65) de modo que mesmo sabendo que as figuras representadas estão paradas (o que é visto) nós também vemos o movimento representado acontecendo (em coextensão) como se estivéssemos assistindo uma ação dinâmica. ${ }^{13}$

Outro aspecto peculiar na representação de figuras humanas por Bajado é que os corpos masculinos e femininos possuem a mesma corpulência, como se o artista houvesse criado uma única estrutura base para figuras humanas da qual posteriormente ele introduziria "elementos generificados" ou "indicativos de gênero" como seios, cabelos longos, barba, bigode, etc. Observa-se na comparação entre figuras masculina e feminina na figura 6 e pela impossibilidade de definição de gêneros a partir dos recortes de pernas na figura 10 .

Os aspectos figurativos da moda daquele tempo também são visíveis nas pinturas de Bajado como podemos observar nos saltos plataformas que aparecem em quadros como "O Homem da Meia Noite e Bajado" (figura 7), como também é comum nos deparamos com cortes de cabelo do tipo black power (figura 8). O artista era famoso por representar personalidades da cultura pop como jogadores de futebol, moradores notáveis do sítio histórico, palhaços do lendário Circo Nerino e até mesmo Dom Hélder Câmara.

\footnotetext{
${ }^{12}$ Disponível em: <https://jc.ne10.uol.com.br/canal/cidades/jc-na-folia/noticia/2016/01/29/museu-da-cidade-do-recifelanca-postais-com-imagens-do-carnaval-219028.php>.

${ }^{13}$ Clive Ashwin (1979) em: The ingredients of style in contemporary illustration: a case study. E Renata Garcia Wanderley (2006) em: Uma abordagem para a representação gráfica de ações dinâmicas.
} 
Figura 7: O Homem da Meia-Noite e Bajado (1980). (Fonte: Casa Bajado de Arte)

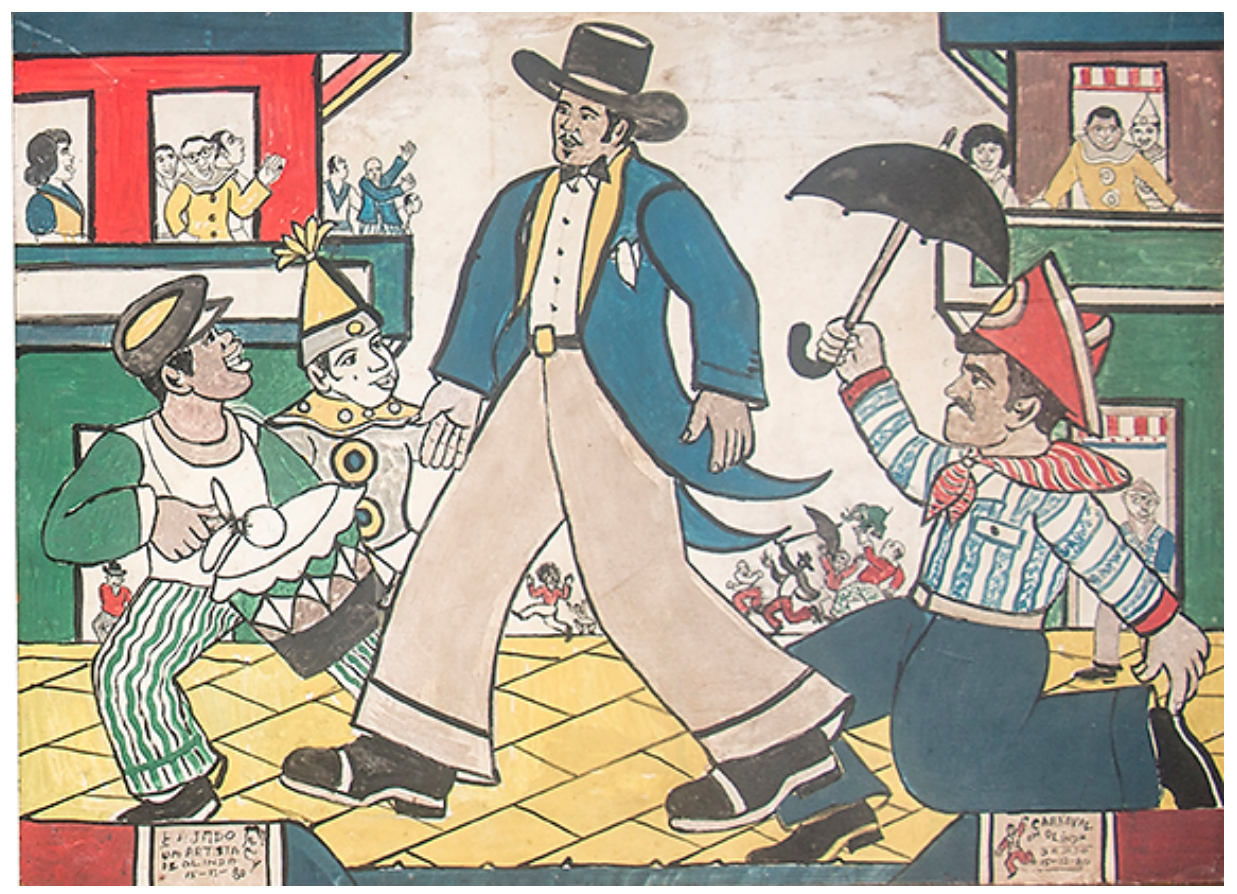

Figura 8: Personagens da cultura popular local. (Fonte: Santa Cruz Futebol Clube) ${ }^{14}$
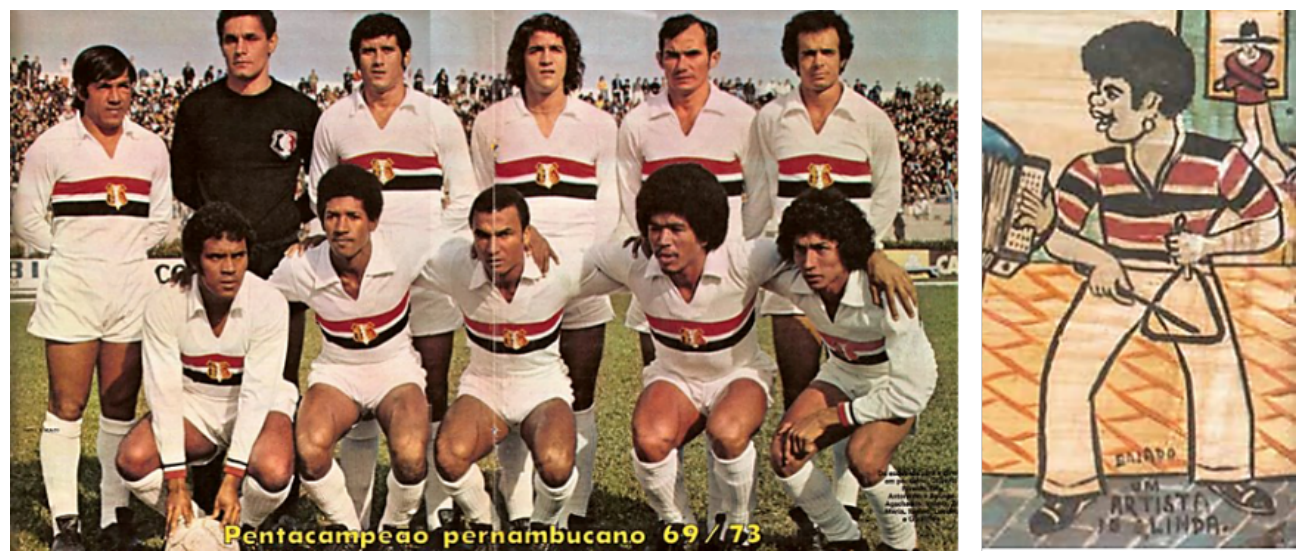

Bajado também parecia ter apreço pela representação da estamparia; podemos notar em alguns de seus quadros o esmero pela representação das texturas. Percebemos esse aspecto nas vestes do caçador nórdico na análise de "O Boi Bumbá", nas representações de torcedores do Santa Cruz e também nos brocados e bordados florais dos vestidos das calungas e damas do paço, etc. nos macacões dos pierrôs, a semelhança visual com espécimes da época também é muito perceptível (figura 9).

\footnotetext{
${ }^{14}$ Disponível em: <http://www.santacruzpe.com.br/linha-do-tempo/>. Acesso em 19 de agosto de 2020.
} 
Figura 9: Palhaços do Clube Carnavalesco Misto Vassourinhas em 1961. (Fonte: Vila Digital, FUNDAJ) ${ }^{15}$
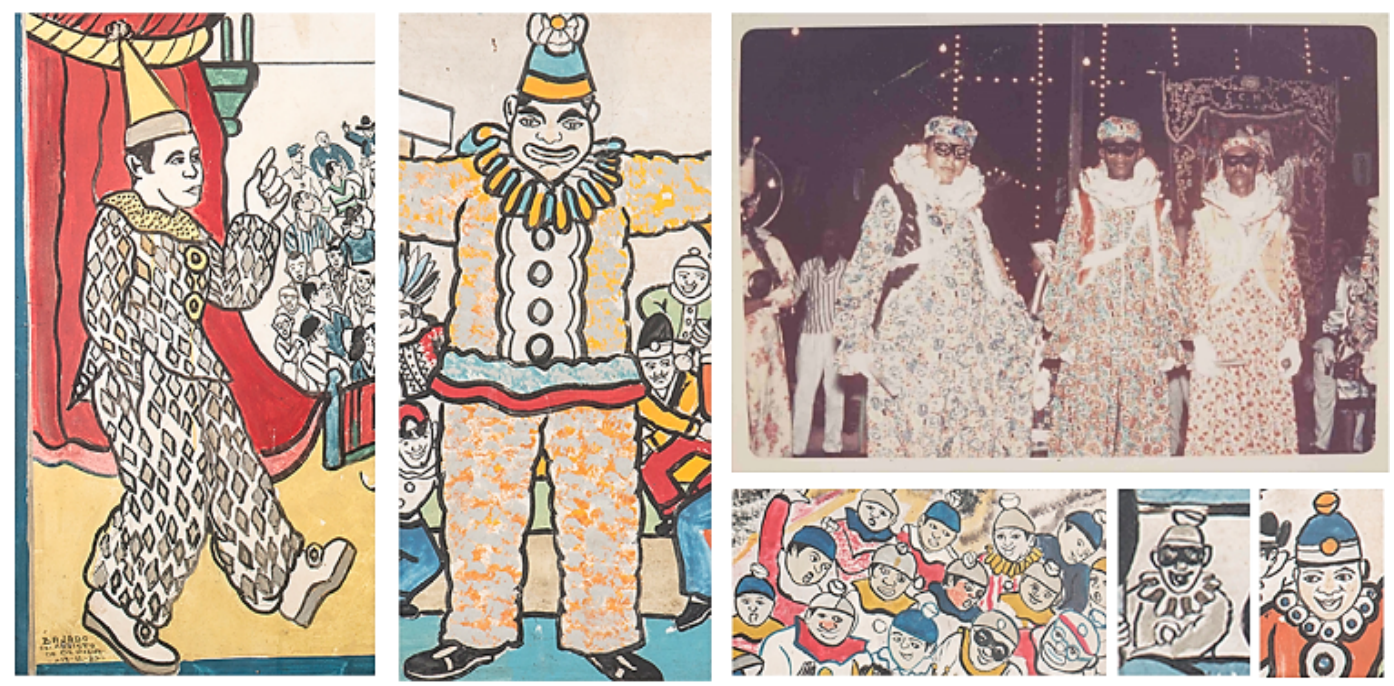

\section{O cuidado de Bajado com a representação da estamparia pode ser percebida pela} variedade de padrões modulares e das cores que aparecem em suas calças (figura 10). Listrados grandes, listrados miúdos, quadriculados, bolinhas, manchadas, etc. Olhar para as pernas dos personagens de Bajado é se deparar com uma alegre coleção de padronagens. $O$ Interessante sobre esse aspecto é que as texturas aplicadas também dão mais evidência aos gestos frenéticos que eles executam como uma "fala invisível", mas perceptível em seu trabalho. Para Gombrich, em "ação e expressão na arte ocidental"

A "linguagem" dos gestos pode ser comparada à linguagem das palavras - cada movimento simbólico tem um "tom" que transmite caráter e emoção; ele pode ser tenso ou relaxado, urgente ou calmo.

Há inúmeros temas tradicionais na arte ocidental que nos permitem estudar essas possibilidades que Dante chama de "fala invisível" (Gombrich, 2012, p. 126).

Assim como a cinética privilegia os membros inferiores dos corpos dos personagens, onde o trabalho de deslocamento dos pontos de equilíbrio é mais verificado; as estampas, justamente nas áreas das pernas, nos fazem imaginar que Bajado investiu - inconscientemente, talvez na ênfase dos membros inferiores justamente por serem os mais expressivos na execução dos passos de frevo. Porque nesse tipo de dança, as pernas são as verdadeiras protagonistas; elas se abrem e fecham, saltam, se cruzam e descruzam, são esticadas, dobradas, retorcidas etc. Nesse sentido, as estampas vibrantes em contraste cromático são tão convincentes que podemos imaginar a sensação tátil que o tecido poderia nos proporcionar; essa é uma das características mais fortes do conceito de ver em:

Trata-se de um tipo bem definido de percepção desencadeado pela presença no campo visual de uma superfície diferenciada. Nem todas as superfícies diferenciadas provocam esse efeito [...] quando uma superfície é adequada, temos a experiência de uma certa fenomenologia característica do ver em. (Wollheim, 2002, p.45-46).

\footnotetext{
${ }^{15}$ Disponível em: <http://villadigital.fundaj.gov.br/index.php/base-da-villa-digital/iconografia/item/3769-palhacos-doclube-carnavalesco-misto-vassourinhas>
} 
Figura 10: As estamparias de Bajado (recortes da pesquisa). (Fonte: Casa Bajado de Arte)
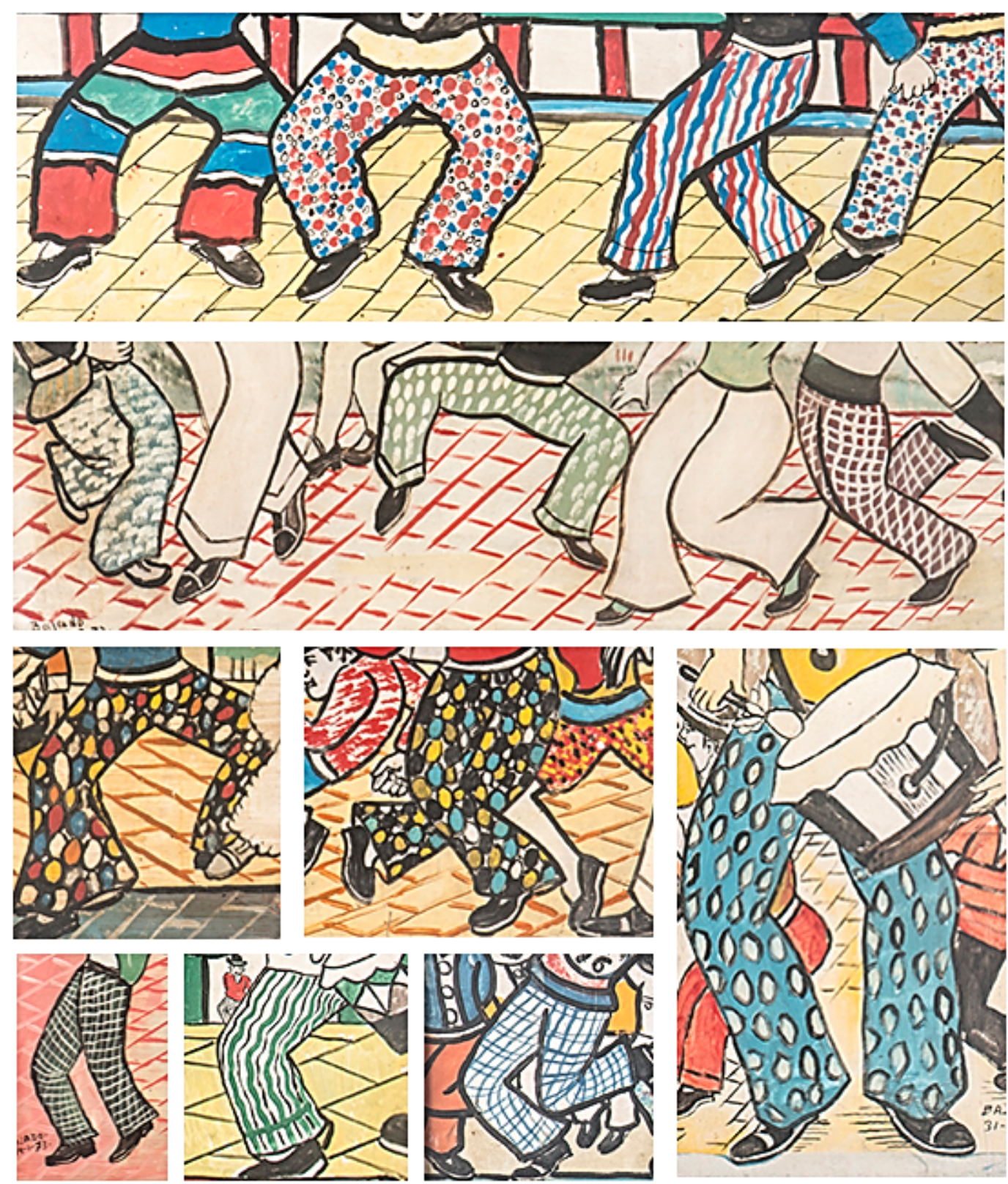
Figura 11: Enquadramentos cinematográficos. (Fonte: capturada do filme Monstro da Lagoa Negra)
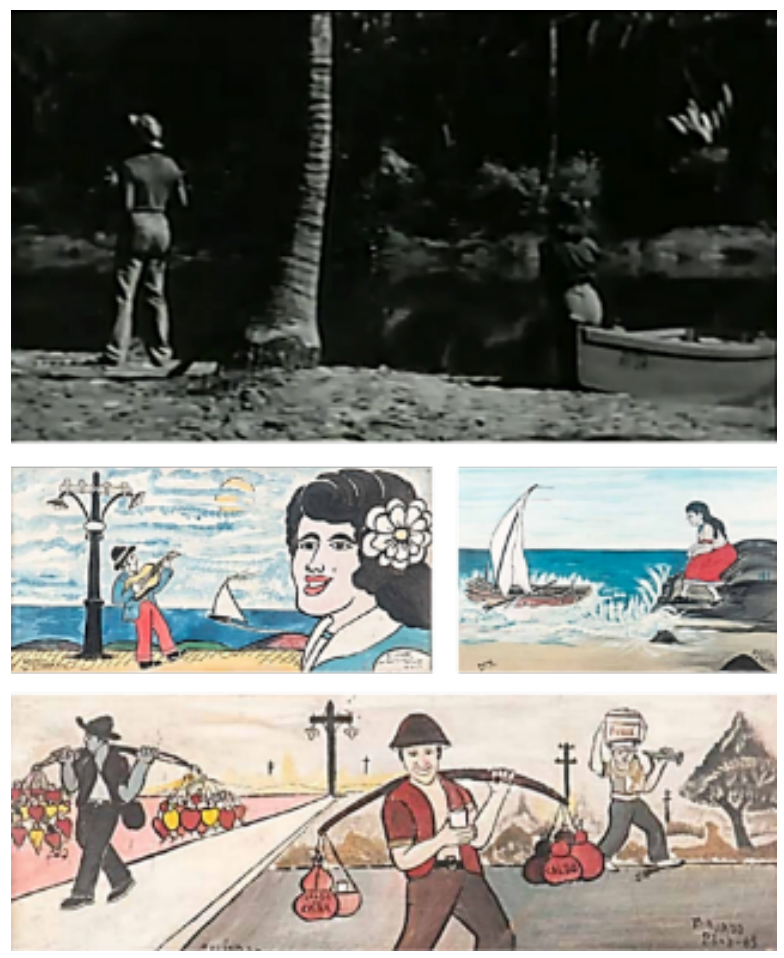

Conforme mencionamos no início deste trabalho, percebemos em Bajado uma predileção pelo enquadramento em plano geral (Aumont, 1993). Por outro lado, ele também utilizava outros enquadramentos além do plano geral; é o caso do close e do plano americano (figura 11). Bajado, que trabalhou durante alguns anos como bilheteiro e artista gráfico do Cine Olinda, também era cinéfilo e existe uma correspondência entre os enquadramentos das pinturas com aqueles que eram utilizados nos filmes que Bajado assistia. É o caso do Monstro da Lagoa Negra (1954) ${ }^{16}$ (figura 11). O mais interessante sobre esse filme é a semelhança que existe entre a aparência do monstro da lagoa e os dragões das séries de São Jorge (figura 12) no tocante a textura escamosa da pele, o formato da cabeça e das garras. O Monstro da Lagoa Negra, segundo Zé Carlos Viana (2016) era um dos preferidos de Bajado ${ }^{17}$.Também é notável a semelhança entre os enquadramentos e trajes da "Missa dos Cangaceiros" com alguns enquadramentos e figurinos do filme Os três Cangaceiros (1959) ${ }^{18}$ (figura 13). No entanto, tudo o que afirmamos são apenas possibilidades, porque concordamos que:

As imagens não equivalem a declarações; perguntar toda vez o que uma pintura "significa" é tão inútil quanto perguntar o mesmo em relação a um prédio, uma sinfonia ou a uma refeição com três pratos. A pintura de uma paisagem iluminada pela lua não "significa" uma paisagem iluminada pela lua, apenas a representa. (Gombrich, 2012, p. 522).

\footnotetext{
${ }^{16}$ Dirigido por Jack Arnold e lançado nos Estados Unidos em 12.02.1954.

${ }^{17}$ Viana em Bajado (2016). Direção de Marcelo Pinheiro.

${ }^{18}$ Direção de Victor Lima, lançado no Brasil em 1959.
} 
Figura 12: Semelhanças com personagens do cinema. (Fonte: folhauol.com.br) ${ }^{19}$
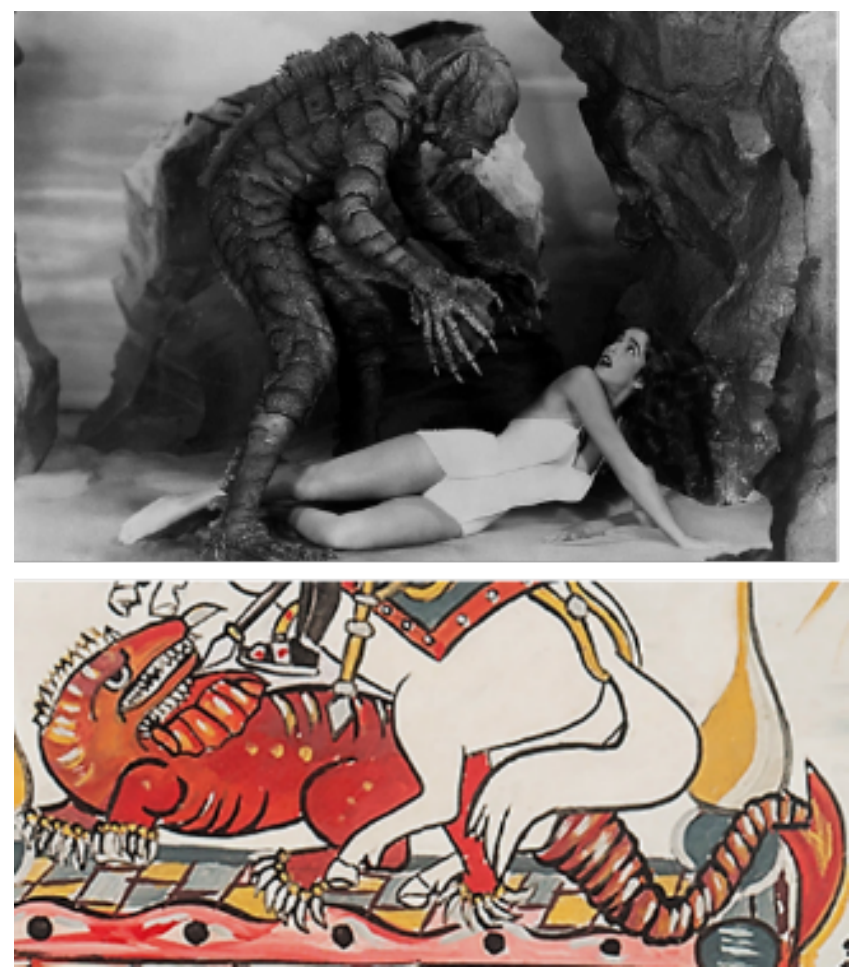

Figura 13: Semelhanças com personagens do cinema. (Fonte: capturadas do filme Os três cangaceiros)
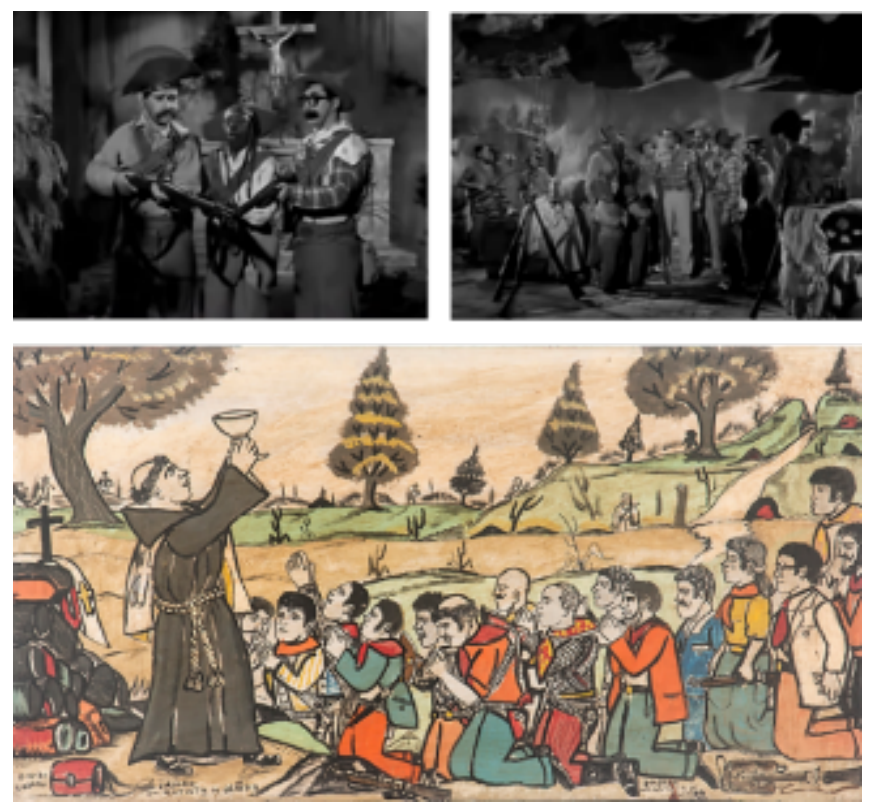

\footnotetext{
${ }^{19}$ Disponível em: <https://guia.folha.uol.com.br/cinema/2018/02/o-monstro-da-lagoa-negra-que-inspirou-a-forma-daagua-sera-exibido-no-ims.shtml>
} 
Figura 14: Semelhanças com personagens do cinema. (Fonte: capturada do filme O Ébrio)
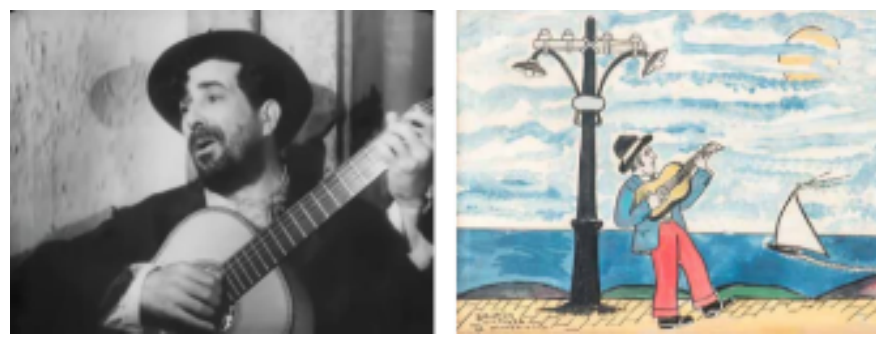

Figura 15: Semelhanças com personagens do cinema. (Fonte: capturada do filme Matar ou Correr)
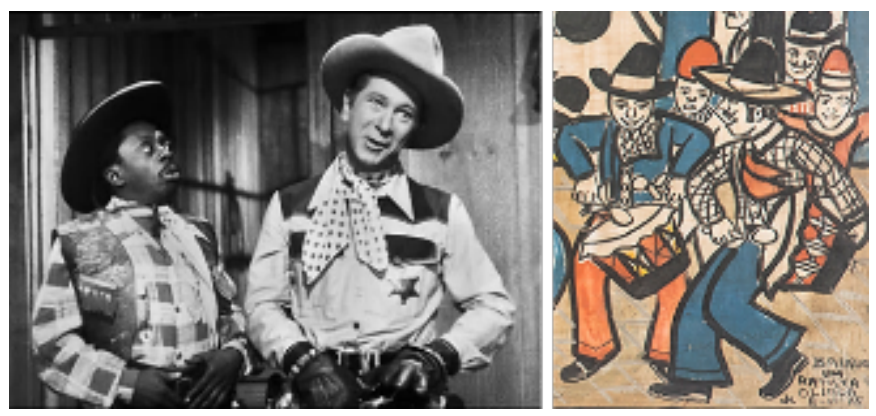

Outros personagens do cinema como é o caso do protagonista de O Ébrio $(1946)^{20}$, e os cowboys brasileiros de Matar ou Correr (1954) $)^{21}$ aparentemente foram representados por Bajado em suas narrativas bricoladas (figuras 14 e 15). Segundo Deda Bajado, filha do artista, Bajado conheceu pessoalmente artistas do cinema nacional como Oscarito (1906-1970), Grande Otelo (1915-1993) e Vicente Celestino (1894-1968) (Pinheiro, 2016; Prado, 1997). A rainha de "Nosso Maracatu I", também é um personagem interessante no sentido que a expressão da sua forma, em suas cores, na aparência do cabelo, tanto quanto pela presença da maçã, a aproxima formalmente da Branca de Neve (1938) que protagoniza a versão animada da Walt Disney (figura 16).

Figura 16: Semelhanças com personagens do cinema. (Fonte: capturada da animação Branca de Neve)
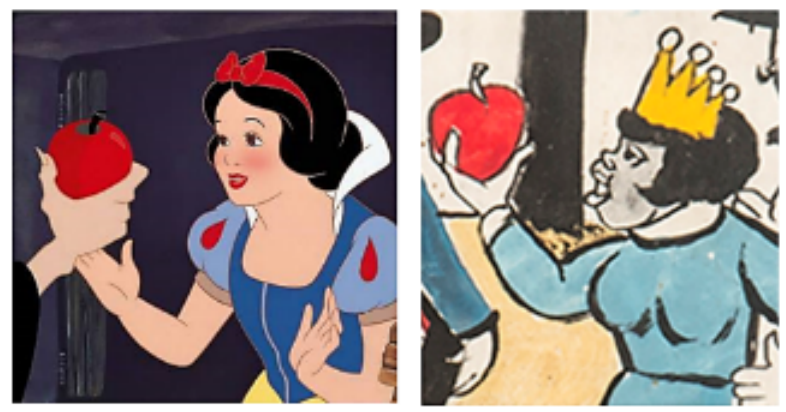

Segundo Wollheim, os historiadores da arte normalmente buscam "inferir a maneira correta de ver a representação a partir da maneira segundo a qual efetivamente a vê, ou pode

\footnotetext{
${ }^{20}$ Dirigido por Gilda Abreu, lançado no Brasil em 1946.

${ }^{21}$ Direção de Carlos Manga, lançada no Brasil em 1954.
} 
reconstituir a intenção do artista a partir do que lhe é visível na pintura" (Wollheim, 1993, p.179). Nesse sentido, essa breve análise das referências visuais que possivelmente serviram como fontes para as bricolagens feitas por Bajado mostra o quanto pode ser inesgotável o estudo da formação do olhar de um indivíduo. Bajado $(1984,1980)$, que quase sempre declarava só pintar aquilo que "era dele" e "criação dele", ao se apropriar de elementos do seu gosto e da sua simpatia, recortados dos produtos culturais que consumia, ao (re)significá-los no seio das suas narrativas, construiu, de maneira original, o seu próprio microuniverso semântico (figura 17).

Figura 17: O microuniverso semântico de Bajado. (Fonte: Casa Bajado de Arte com fotocomposição elaborada por Santana)

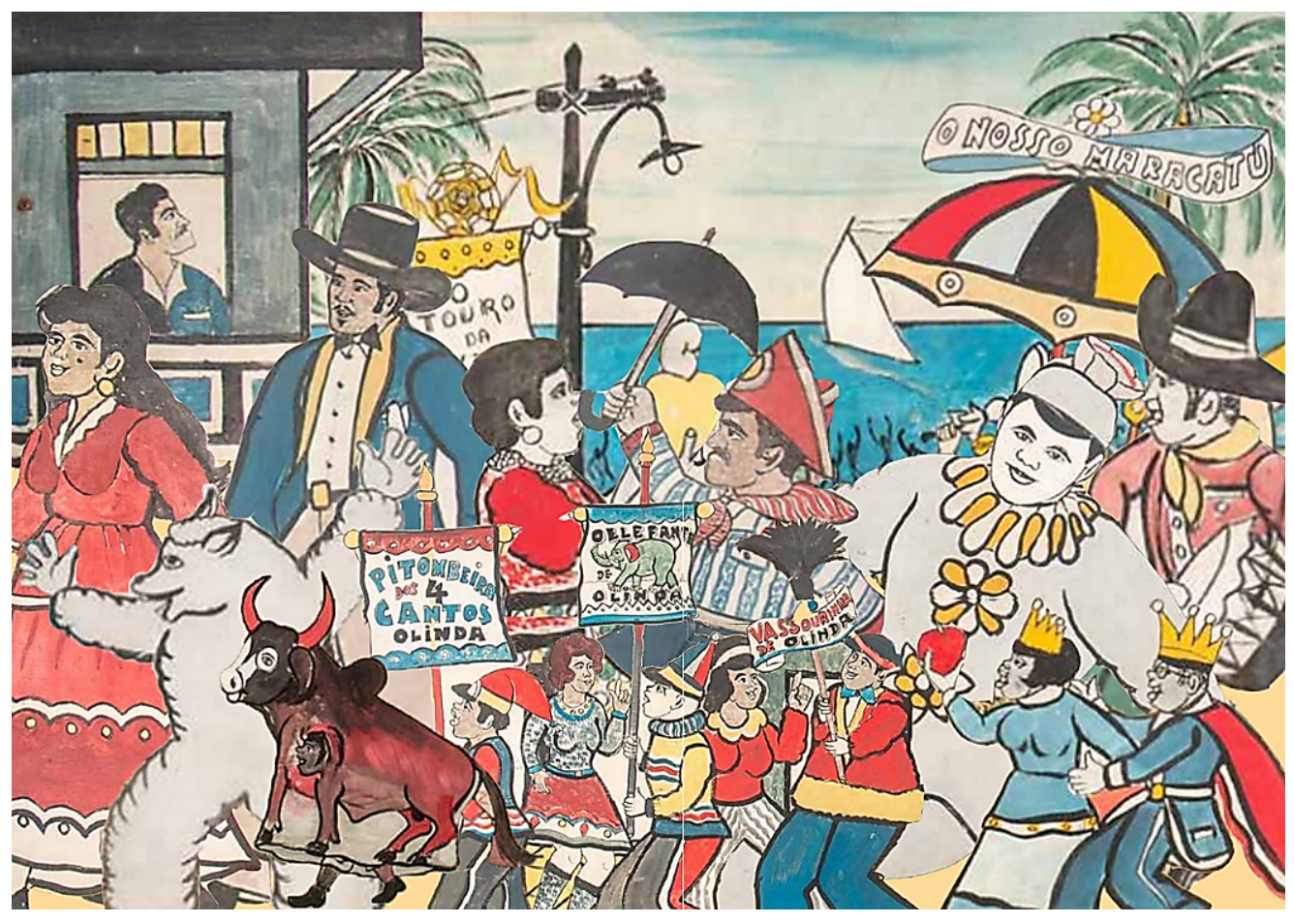

\section{Notas finais}

Para concluir, consideramos que toda representação guarda uma intenção, quando falamos em intenção não nos referimos a significação, o ver em é caracterizado por uma dualidade "tenho consciência visual da superfície para a qual estou olhando e, ao mesmo tempo, distingo na frente dela uma outra coisa que avança, ou, em certos casos, recua" (Wollheim, 1993, p.46). Se consideramos que "estudos sobre memória gráfica e cultura visual compartilham o interesse de compreender o modo como a sociedade seleciona ou cria imagens e formas visuais, e, ao mesmo tempo, como essa sociedade, em certo sentido, se reflete em tais imagens e formas" (Farias \& Braga, 2018, p.13). Ainda que os objetos aqui analisados pertençam a ordem dos artefatos de arte, é perceptível que, em termos de informação visual, esses quadros desempenham uma função similar a qualquer objeto efêmero impresso. 
Numa pintura que conta a história do cortejo de um boi-bumbá contém informações caras à cultura visual (na representação do folguedo popular e seus atores sociais), à memória gráfica (o cowboy que porta um tambor e integra a batucada tem as feições de um ator popular, um jogador de futebol, um político da época, etc.) e ao Design da Informação (no detalhe da estampa do saiote do boi, na representação do cinetismo dos brincantes, no enquadramento etc.).

Diante disso, é de notória relevância a contribuição de Bajado ao inventário de imagens que compõem a memória gráfica pernambucana e brasileira; e enquanto pesquisadores da memória gráfica, é necessário que estejamos abertos a expandir os nossos olhares para as fronteiras dos objetos efêmeros. Assim como é importante considerarmos o hibridismo morfológico dos objetos da memória gráfica; é igualmente salutar considerarmos a pluralidade dos seus conteúdos, pois o caso Bajado também evidencia que às vezes um traço distinto, um "modo" específico e identitário de representar movimentos, objetos, pessoas e animais, um esquema de cores etc., são suficientes para que um observador revisite afetos, situações e experiências vividas e guardadas na memória.

\section{Referências}

Ashwin, C. (1979). The ingredients of style in contemporary illustration: a case study. In Information Design Journal, 1(1), 51-67.

Aumont, J. (1993). A imagem. Campinas, SP: Papirus.

Bajado. (1984). Bajado um artista de Olinda. Tv Viva (02:45 min), son., color. Youtube. Disponível em: <https://www.youtube.com/watch?v=OgYR4OdRrvM\&t=7s>.

Bajado. (1980). Entrevista sobre vida e obra. In. Revista trimestral vidas secas: realidade, cultura e o escambau. (2) Set-Out-Nov. - Recife: Editora Universitária.

Bertin, J. (2010 [1967]). Semiology of Graphics. Madison, Wisconsin: University of Wisconsin Press.

Cuentro, J. (1985). Org. Bajado, um artista de Olinda. Olinda: Fundação centro de preservação dos sítios históricos de Olinda.

Farias, P., \& Braga, M. C. (2018). Dez ensaios sobre memória gráfica. São Paulo: Blucher.

Floch, J.-M. (2004). De uma crítica ideológica da arte a uma mitologia da criação artística: Immendorf 1973-1988. In: Oliveira, A. C. (Org.). Semiótica plástica. (pp. 243-262). São Paulo: Hacker editores.

Floch, J.-M. (1985). Petites mythologies de l'œil et de l'esprit. Pour une sémiotique plastique. Actes Sémiotique. Paris-Amsterdan: Hadès Benjamine.

Gombrich, E.H. (2012). Gombrich essencial: textos selecionados sobre arte e cultura Organizado por Richard Wooldfiel. Porto Alegre: Bookman.

Greimas, A. J. (1966). Condições de uma semântica científica. Semântica estrutural. (pp. 1126). São Paulo: Cultrix.

Greimas, A. J. (2004). Semiótica figurativa e semiótica plástica [1984]. In: Oliveira, A. C. (Org.). Semiótica plástica. (pp. 75-96). São Paulo: Hacker editores. 
Mesel, K. (1981). Bajado um artista de Olinda. Direção de Katia Mesel. Recife: Arrecife Produções Cinematográficas, Blow-up Produções Cinematográficas Ltda (12 min), son., color. Fundaj. Disponível em: <http://cinematecapernambucana.com.br/filme/?id=2501>.

Pinheiro, M. (2016). Bajado. Direção de Marcelo Pinheiro. Recife: Opara Filmes (20:19 min), son., color. Vimeo. Disponível em: <https://vimeo.com/127163768>.

Prado, G. (1997). Bajado. Recife: Cepe.

Santana, R. (2020). Bajado a poética visual no discurso gráfico: diálogo entre a Semiótica Estruturalista e o Design da Informação. [Dissertação de Mestrado não publicada]. Programa de Pós-graduação em Design, Universidade Federal de Pernambuco, Recife.

Santana, R., \& Miranda, E. R. (2019). Redescobrindo Bajado: artista reconhecido, designer esquecido. Anais do Congresso Internacional de Design da Informação, 9, 2347-2360. https://doi.org/10.5151/9cidi-congic-5.0224

Twyman, M. (1985). Using pictorial language: a discussion of the dimensions of the problem. In Dufty, T. M., \& Waller, R. (Eds.) Designing usable texts. (pp. 245-312). Orlando, Florida: Academic Press.

Twyman, M. (1982). The graphic presentation of language. Information Design Journal, 3/1, 2-22.

Twyman, M. (1979). A schema for the study of graphic language. In Kolers, P.A.; Wrostad, M.E., \& Bouma, H. (Eds.) The Processing of Visible Language, vol. 1, (pp. 117-150). New York: Plenum.

Viana, J.C. (2016). Bajado. Direção de Marcelo Pinheiro. Recife: Opara Filmes. Disponível em: $<$ https://vimeo.com/127163768>.

Wanderley, R. G. (2006). Uma abordagem para a representação gráfica de ações dinâmicas. Recife. [Dissertação de Mestrado não publicada]. Programa de Pós-graduação em Design, Universidade Federal de Pernambuco, Recife.

Wollheim, R. (2002). A pintura como arte. Tradução de Vera Pereira. São Paulo: Cosac \& Naify.

Wollheim, R. (1993). A arte e seus objetos. Tradução de Marcelo Brandão Cipolla. São Paulo: Martins fontes.

\section{Sobre as autoras}

Rafa Santana, Mestra, UFPE, Brasil <rafael.santanasouza@ufpe.br> Eva Rolim Miranda, Doutora, UFAL, Brasil <eva.miranda@fau.ufal.br> Solange Galvão Coutinho, PhD, UFPE, Brasil <solange.coutinho@ufpe.br> 